\title{
Macalester International
}

Volume 9 After Apartheid: South Africa in the New

Century

Article 16

Fall 12-31-2000

\section{Multicultural Feminism Transforming Democracy}

Duchess Harris

MacalesterCollege, harris@macalester.edu

Follow this and additional works at: http://digitalcommons.macalester.edu/macintl

\section{Recommended Citation}

Harris, Duchess (2000) "Multicultural Feminism Transforming Democracy," Macalester International: Vol. 9, Article 16.

Available at: http://digitalcommons.macalester.edu/macintl/vol9/iss1/16

This Article is brought to you for free and open access by the Institute for Global Citizenship at DigitalCommons@Macalester College. It has been accepted for inclusion in Macalester International by an authorized administrator of DigitalCommons@Macalester College. For more information, please contactscholarpub@macalester.edu. 


\section{Multicultural Feminism Transforming Democracy}

\section{Duchess Harris}

The transformation of silence into language and action is an act of self-revelation, and is therefore dangerous. Audre Lorde

Meanwhile, in the real world, gender continues to be one of the most important sites of transformation in the African region. Politicians and policy-makers frequently display a politically correct concern with gender inequality, only to founder when it comes to implementing change.

\section{-African Gender Institute Newsletter, University of Capetown}

Wy intellectual development has been informed by several experiences at Macalester College, but developing a course on Critical Race Feminism exposed me to a body of knowledge that has transformed my classroom performance. Critical Race Feminism is a new legal genre that is part of an evolving tradition within the legal academy that began with Critical Legal Studies (CLS). Adrien Katherine Wing characterizes CLS as an intellectual tradition that embraces postmodern critiques of individualism and hierarchy in modern Western society. A primary method of analysis for critical scholars is deconstruction, which entails analyzing supposedly neutral concepts to show the true nature of the contingent power relationships they mask and conceal. ${ }^{1}$ The major players in this movement were "radical" white men. Their organizing was followed by the Feminist Jurisprudence and the Critical Race Theory movements. These movements were led by, but not exclusively made up of, white women and Black ${ }^{2}$ men, respectively. Wing writes, "Fundamental to Critical Race Feminism is the idea that women of color are not simply white women plus some ineffable and secondary characteristics, such as skin tone, added on." ${ }^{\prime 3}$

Clearly this genre is informed by Deborah King's insightful theory that a Black feminist ideology should be multiplicative, as opposed to additive. In her essay, "Multiple Jeopardy, Multiple Consciousness: The Context of a Black Feminist Ideology," Deborah King posits that 
an interactive model is necessary to analyze oppression of Black women. She defines this by stating that racism plus sexism plus classism is not an equitable equation. Black feminist scholars eschew additive analyses that suggest that a woman's racial identity can be "subtracted" from her combined sexual, socioeconomic, and racial identity. ${ }^{4}$ Bonnie Thornton Dill describes Black women's experiences as not only multicultural but also dialectical, since they include not only mutual but contradictory influences. Her dialectical view rejects a "deficit model," which implies that Blacks have difficulty accumulating enough white culture because of economic obstacles and because it is an add-on to their own. ${ }^{5}$ The aforementioned author's notions of a paradigm to theorize Black women is well mapped out by Evelyn Brooks-Higginbotham who argues that we must, "expose the role of race as a metalanguage by calling attention to its powerful, all-encompassing effect on the construction and representation of other social and power relations, namely, gender, class, and sexuality." 6

My fascination with teaching, researching, and publishing in the area of Critical Race Feminism is inspired by Kimberle Crenshaw's observation that the theoretical erasure of Black women in legal scholarship leads to their actual erasure in the law. ${ }^{7}$ This concept is my point of departure to look for answers to the following question: What protection do Black women receive under the Constitutions of the United States and South Africa?

$* * * * *$

So when we looked at de picture and everybody got pointed out there wasn't nobody left except a real dark little girl with long hair standing by Eleanor. Dat's where Ah wus s'posed to be, but I couldn't recognize dat dark chile as me. So Ah ast, where is me? Ah don't see me. ${ }^{8}$

In Zora Neale Hurston's 1937 novel, Their Eyes Were Watching God, the protagonist Janie, a seven year old Black girl, sees a photograph, but does not recognize herself. I would argue that when Black women look at antidiscrimination legal doctrine in the United States, they don't recognize themselves. Crenshaw explains the operative definition of legal discrimination: "Discrimination which is wrongful proceeds from the identification of a specific class or category; either a discriminator intentionally identifies this category, or a process is adopted which disadvantages all members of this category." ${ }^{\prime \prime}$ Crenshaw points out that 
the problem with this definition is that it only allows for a single issue analysis:

This apparent contradiction is but another manifestation of the conceptual limitations of the single-issue analysis that intersectionality challenges. The point is that Black women can experience discrimination in any number of ways and that the contradiction arises from our assumptions that their claims of exclusion must be unidirectional. Consider an analogy to traffic in an intersection, coming and going in all four directions. Discrimination, like traffic through an intersection, may flow in one direction, and it may flow in another. If an accident happens in an intersection, it can be caused by cars traveling from any number of directions and, sometimes, from all of them. Similarly, if a Black woman is harmed because she is at the intersection, her injury could result from sex discrimination or race discrimination.

Judicial decisions which premise intersectional relief on a showing that Black women are specifically recognized as a class are analogous to a doctor's decision at the scene of an accident to treat an accident victim only if the injury is recognized by medical insurance. Similarly, providing legal relief only when Black women show that their claims are based on race or sex is analogous to calling an ambulance for the victim only after the driver responsible for the injuries is identified. ${ }^{10}$

When I first read this passage to prepare to teach my senior seminar on Critical Race Feminism, I realized that a diagram of a "Black woman in the traffic jam of American Apartheid," might be a successful pedagogical tool. Arrogantly American, I tried to bring this theory to the University of Cape Town, not realizing that "post-apartheid" South Africa in the year 2000 is fundamentally different from the "post-Jim Crow" United States. Not only do their "traffic jams" travel in many more directions than ours do, they drive on a different side of the road.

$* * * * *$

My original project for the Macalester International Development Seminar was inspired by an article written by Adrien Katherine Wing and Eunice P. De Carvalho, entitled "Black South African Women: Toward Equal Rights." In their article, they call for an intersectional critique of the Interim South African Constitution. They write, "The intersection of race and gender justifies calls for the creation of a separate constitu- 
tional status for Black women."11 My intent was to interview Black South African women to ask them if they thought this was a viable solution to their relationship to the new South African Constitution. Much of the political transformation in South Africa has focused on the centerpiece of the legal revolution, the new Constitution and Bill of Rights. ${ }^{12}$ In this section of my essay, I will briefly discuss the constitutional history that led up to the Constitution of the Republic of South Africa Act 108 of 1996.

South Africa has traditionally been a male-dominated country, even after the country became a union in 1910. This fact is evident in all walks of life, but especially in public life. Women today still suffer from "Invisibility Blues" ${ }^{13}$ in public life, even though no law has ever been passed to limit the status or role of women per se in South African society. Female representation in the public sector does not reflect the composition of the population (more than half the people in South Africa are women). ${ }^{14}$ In 1930, the Hertzog government enfranchised white women, giving them the right to vote. Black women and men were disenfranchised until 1994. ${ }^{15}$ Black women in pre-1993 South Africa lived under a dual burden of discrimination: apartheid and sexism. This discrimination was promoted through state-sponsored legal instruments, as embodied by the system of law known as apartheid, as well as in tribal systems of law known as "customary law." Most scholars are aware that apartheid imposed on South African Blacks a badge of inferiority in all areas of life, including housing, land ownership, education, health care, employment, judicial administration, freedom of speech, freedom of association, public accommodations, and marriage. What is less familiar to many of us, however, is customary law.

In addition to apartheid, a construction of the state, Black women were subjected to Black male domination under customary law, which affected marriage, guardianship, succession, contractual power, and property rights. Customary law is defined in the Law of Evidence Amendment Act of 1988 as "the Black law or customs as applied by the Black tribes in the Republic or territories which formerly formed part of the Republic." Customary law views women as perpetual minors and lifelong wards of their fathers, husbands, brothers, or sons. Women cannot engage in contracts of any kind, acquire property, inherit, or marry without the permission of a guardian, usually a male relative.

As South Africa enters a new era of empowerment for Blacks with its first universally elected parliament, it must embark on a campaign 
to achieve equality for Black women. The Interim Constitution of 1993 was a significant step toward that end. It guarantees equal protection under the law to all people and prohibits discrimination on the basis of gender. As significantly, the Interim Constitution permits the introduction of affirmative action programs to benefit Black women as well as others discriminated against under apartheid. Yet, despite the promise of a new legal order, the Interim Constitution does not ensure material and practical equality for Black women. The roots of these problems are evident in the initial failure of the Interim Constitution's drafters to seek the input of Black women during the Constitution's genesis. $^{16}$

In a state democracy, the franchise is not only a very important civil right, it signifies the presence of a democratic order. In 1990, the African National Congress (ANC) was unbanned and a process of ongoing negotiations started to transform South Africa into a democratic state. One of the most important aspects of the process of transformation was the acceptance of the Interim Constitution by the role players in this process. As a group, these role players were the people in the Multi-Party Negotiating Process. ${ }^{17}$ They agreed to the Interim Constitution on November 17, 1993, at the World Trade Center in Kempton Park. Women demonstrated outside of the World Trade Center in protest against their exclusion from the Multi-Party Negotiating Process. While this event was given no coverage in the local media, its fruit was the inclusion of women delegates in the discussions that forged the Interim Constitution. ${ }^{18}$ After this protest, it was required that one of each of the negotiating party's two representatives in the Negotiating Council be a woman.

August 9, 1993 (National Women's Day) marked a change in direction for women's politics in South Africa. The parliamentary Joint Standing Committee on Justice met to consider legislation aimed at the promotion of equality between women and men and the prevention of family violence. A few months later, in December, the Prevention of Family Violence Bill was passed, outlawing rape within marriage. This was followed by the Transitional Executive Council establishing a subcouncil on women. The development of the sub-council on women was extraordinary because it elevated gender to a central concern of South African government and politics, on par with six other subcouncils on Regional and Local Government, Law and Order and State Security, Defence, Finance, Foreign Affairs, and Intelligence. ${ }^{19}$ 
In response to the initial exclusion of women from the Convention for a Democratic South Africa constitution-making process, a racially integrated group of women formed a political lobby group, the Women's National Coalition (WNC), to represent the collective demands of South African women. After much discussion, the WNC produced a Women's Charter in 1994 as a collective response to the perceived deficiencies in the Interim Constitution. The document reflected a consensus of a majority of the women involved; and Black women had a central role in the development process and constituted a plurality of the coalition's participants.

The Women's Charter constitutes an important proposal to the drafter of the Permanent Constitution on how to affirm women's rights more effectively. It calls for the principle of equality to be implemented at all levels of government legislation and policy. Specific legislation is sought to ensure social, economic, political, and legal equality for all South African women..$^{20}$

During a short session of the South African Parliament in November and December 1993, the Interim Constitution was adopted into statute (Act 200 of 1993), and Parliament made it a legitimate law of the land. The Interim Constitution came into effect on April 27, 1994, after the first South African election in which all citizens over the age of 18 had the right to vote. ${ }^{21}$ One of the most important aspects of this temporary transitional document was that it laid out the provisions by which a Constitutional Assembly would be convened. The Constitutional Assembly joined the National Assembly and the Senate, with its task to write and adopt a final constitution..$^{22}$ This historic undertaking was completed on May 10, 1996, and the final Constitution became law in February 1997.

My initial thoughts about my trip to "post-apartheid" South Africa were naively hopeful. The creation of a sub-council on the status of women by the Interim Parliament of South Africa seemed remarkably similar to a move of John F. Kennedy's administration. On December 14, 1961, more than four years before the emergence of a vigorous wave of feminism, President John F. Kennedy established the President's Commission on the Status of Women (PCSW). The creation of the commission, which one newspaper hailed as the launching of a "Distaf 'Fair Deal,'" denoted a fundamental shift in federal policy 
expressed also in the enactment of equal pay legislation (1963) and the repeal of the prohibition against women in the federal services.

The creation of the President's Commission gave a new legitimacy to the struggle against discrimination based on sex and initiated an ongoing national discussion on gender equality. As Betty Friedan wrote in 1963, "the very existence of the President's Commission on the Status of Women, under Eleanor Roosevelt's leadership, creates a climate where it is possible to recognize and do something about discrimination against women, in terms not only of pay but of subtle barriers to opportunity." The membership of the commission and its subsidiary bodies represented many constituencies. Fifteen women served with eleven men on the commission itself, with ten members of the commission coming from the federal government, including the Attorney General, the Chairman of the Civil Services Commission, and the secretaries of the departments of Commerce, Agriculture, Labor, and Health, Education and Welfare. The director of the Women's Bureau, Esther Peterson, with Secretary of Labor Arthur Goldberg, dominated the selection procedures, choosing from women's organizations, labor unions, educational institutions, and governmental agencies to supply more than 120 participants for the commission and its seven technical committees. No official of the National Women's Party was invited to join the commission although Peters did include two women who were members of the pro-ERA National Federation of Business and Professional Women's Clubs. A Commission without ERA support would lack credibility, and Peters cleared the way for the two groups' participation by omitting a statement of purpose indicating a preconceived position of the amendment. In order to cover some areas in depth, the PCSW held four meetings on private employment opportunities, new patterns of volunteer work, portrayals of women by the media, and the problems of Negro women. The inclusion of the last reflects the commission's acknowledgment of the problems of dual discrimination borne by Black women. The Consultation on Negro Women was chaired by Dorothy I. Height. Although meetings were held, the Negro women's voices were never heard. On October 12, 1963, the twenty-four suggestions of the PCSW were covered on the front page of the New York Times. None of the conclusions of the Fourth Consultation were incorporated into these suggestions, and Negro women were not mentioned at all..$^{23}$

When I traveled to South Africa on January 3, 2000, I thought that Black women would be politically situated similarly to Dorothy 
Height on 1963. I couldn't have been more wrong. After spending three weeks in the country, their situation seemed to be more reminiscent of Sojourner Truth at Seneca Falls. Given the regressive state of sexual politics in South Africa, I was both surprised and somewhat skeptical of addressing their concerns from within the Academy. Dr. Mamphele Ramphele of the University of Cape Town, however, saw the creation of the African Gender Institute as one solution to the multifaceted problem of gender inequity in South Africa.

$* * * * *$

The Equal Opportunity Research Project was established at the University of Cape Town (UCT) in 1991 under the directorship of Dr. Mamphela Ramphele, then Deputy Vice-Chancellor at UCT. The mission of the African Gender Institute (AGI) is twofold: the first is to support women academics and researchers generally; the second is to support gender policy research. ${ }^{24}$ The African Gender Institute was established in 1996, and is now led by Professor Amina Mama. According to an AGI newsletter, the Institute's objectives are the following:

- contribute to the design and implementation of gender redistributive and transformative policies and practices

- provide support to African women and men who have the potential to influence and effect change towards equity

- develop a better understanding of both equity in Africa and mechanisms for its application in different contexts

- increase the limited pool of African women who would be able to take up leading roles in academia or society more broadly

- facilitate the development of courses and academic programmes which include gender as a tool of social analysis

- build a documentation and information centre supportive of AGI goals

By the year 2000, these goals had been met and I was fortunate enough to be on campus the week that AGI's new graduate program in Gender and Transformation was being launched. As someone who was trained at the Center for Advanced Feminist Studies at the University of Minnesota, I accept as fundamental the notion that academic gender studies create praxis. My concern about how feminist theory 
functions within the context of South Africa, however, is one of historical moment. In the United States, Black women were not able to create a Black feminist movement that bridged activism and the academy until after the second Reconstruction (the Civil Rights movement). Because South Africa has not transformed as much as many of us would like, or as much as many of us were led to believe, I wonder if such a program would function as a form of trickle-down liberation. My concerns are informed by the status of Black South African women in the post-apartheid era. They exist in what I call a matrix of inequality.

Gender disparity in South Africa is entrenched by an economy that is structured on a sexual division of labor, compounded by ethnic, regional, and class divisions. ${ }^{25}$ The research that I conducted during the month was most informed by a text that I found at the University of Western Cape. I was inspired by a passage in an article on the position of women toward a transition to governance:

We need to question the patriarchal nature of the state and how it colludes in the sexual division of labour by allowing the perpetuation of gender inequalities in both the domestic and public spheres. Unless there is a radical restructuring in terms of sexual division of labour, with a concomitant change in the consciousness, discourse and behaviour of men and women in relation to gender roles, women will remain mere wives, mothers and lovers instead of enjoying citizenship in their own right. ${ }^{26}$

I would argue that a feminist project within the University system in a country where an estimated three million Black women are functionally illiterate, ${ }^{27}$ may remove a weed, but leaves the root. By comparison, in the United States during Reconstruction, Black women removed the weeds of injustice with grassroots organization, as well as intellectual uplift. In contrast, the project of the African Gender Institute feels somewhat DuBoisian, ${ }^{28}$ that is, it seeks to liberate a very small cadre of elites, who will in turn attempt to liberate the "masses." It is my hope that the academic solutions posed by the African Gender Institute function more like the Black women's club movement of the late 19th century than DuBois' elitist "talented tenth." I hope that the women at the University of Cape Town employ the motto, "Lifting as We Climb," of the National Association of Colored Women, which was formed in 1896. This would make sense because, for Black women, 


\section{Duchess Harris}

\section{South Africa in the millennium is like South Carolina during the Anti- Lynching movement.}

\section{Notes}

1. Adrien Katherine Wing, Critical Race Feminism (New York: NYU Press, 1997), 2.

2. In other publications, I use the terms Black and African-American interchangeably. I prefer the term Black for two reasons. The term Black succinctly describes a racial group that is politically cohesive, historically stigmatized, economically depressed, and socially isolated. I also feel that the term merits capitalization. In a South African context, I use "Black" to denote the populations that the apartheid government designated as "coloured" and "black."

3. Wing, 3 .

4. Deborah King, "Multiple Jeopardy, Multiple Consciousness: The Context of Black Feminist Ideology," SIGNS 12, no. 2 (Autumn 1988): 42-72.

5. Bonnie Thornton Dill, "Dialectics of Black Womanhood," SIGNS 4, no. 3 (Spring 1979).

6. Evelyn Brooks Higginbotham, "African-American Women's History and the Metalanguage of Race," SIGNS 17, no. 2 (Winter 1992).

7. Kimberle Crenshaw, "Demarginalizing the Intersection of Race and Sex: A Black Feminist Critique of Antidiscrimination Doctrine, Feminist Theory, and Antiracist Politics," Harvard Law Review (1989): 63.

8. Zora Neale Hurston, Their Eyes Were Watching God (New York: Harper and Row, 1937).

9. Crenshaw, 63.

10. Crenshaw, Critical Race Feminism, 393.

11. Penelope Andrews, "Symposium: Violence against Women in South Africa: The Role of Culture and the Limitations of the Law," Temple Political and Civil Rights Law Review (1999): 427.

12. Women and the Law in South Africa, 220.

13. Michele Wallace, Invisibility Blues: From Pop to Culture (New York: NYU Press, 1994).

14. Women and the Law in South Africa, 222

15. Adrien Katherine Wing, "Conceptualizing Violence: Present and Future Developments in International Law: A Critical Race Feminist Conceptualization of Violence," Albany Law Review (1997).

16. Ibid.

17. Rhoda Kadalie, "Women in the New South Africa: From Transition to Governance," The Constitution of South Africa from a Gender Perspective, 64

18. Ibid.

19. Ibid.

20. Ibid., 222.

21. South African Women and the Law, 223.

22. Duchess Harris, Journal of Intergroup Relations (Spring 1997): 57.

23. Equal Opportunity Research Grant 
24. Kadalie, 72.

25. Ibid., 77.

26. Debbie Budlender, "Women in Economic Development," in South African Review: From "Red Friday" to Codesa, edited by Moss and Obery (Johannesburg: Ravan Press, 1992).

27. Ibid.

28. In the early 20th century, Black American scholar and public intellectual W.E.B. DuBois theorized that the "uplift" of Black Americans would be accomplished by educating the upper tenth of the Black American population. This upper tenth would form the intellectual "vanguard" that would lead the "masses." See W.E.B. DuBois, The Souls of Black Folk (New York: Signet Classic, 1982). 